\title{
LETTERS FROM MY FUTURE SELF
}

\author{
by
}

\author{
Ashleigh Larratt \\ Bachelor of Arts (Honours) in Film and Media \\ Queen's University, 2006
}

\begin{abstract}
A Major Research Paper
Presented to Ryerson University

in partial fulfillment of the requirements of the degree of Master of Fine Arts in the Program of Documentary Media
\end{abstract}

Toronto, Ontario, Canada, 2019

(C) Ashleigh Larratt 2019 


\section{Author's Declaration}

I hereby declare that I am the sole author of this MRP. This is a true copy of the MRP, including any required final revisions.

I authorize Ryerson University to lend this MRP to other institutions or individuals for the purpose of scholarly research.

I further authorize Ryerson University to reproduce this MRP by photocopying or by other means, in total or in part, at the request of other institutions or individuals for the purpose of scholarly research.

I understand that my MRP may be electronically available to the public. 


\author{
Abstract \\ Letters From My Future Self \\ Masters of Fine Arts \\ 2019 Ashleigh Larratt \\ Documentary Media \\ Ryerson University
}

What does it mean to become the person you are meant to be? How can embodied wholeness be realized, no matter what happened, and become an exhilarating point of departure for creative practice, and ultimately, life.

In Letters From my Future Self, my thirty-six minute experimental film, I try to answer this question with material from my own life. By making art out of my personal history, and the mystical vision of a Future Self, trauma becomes a portal for healing, and discovering the beauty of the present moment.

In doing so, I offer my story as a template for others' healing. I encourage viewers to embark on their own inward journeys of self-discovery. To enlighten that which they most wish to hide from and push away. To merge their divinity with their humanity, becoming their own Future Selves. 


\section{Acknowledgements}

I would like to express my sincere gratitude to my advisors, Gerda Cammaer and Pierre Tremblay. Gerda, I have always felt, since the inception of this work, that you were a compass for the highest spiritual vision of the film. That you were fiercely protecting the gold within it. Your exquisitely refined artistic and visual sensitivity served as a guiding hand, holding this equally precious and challenging journey. To Pierre, your brilliantly astute feedback at various points, guided me through critical creative choice points. I knew from our first meeting that you would have enough distance from the subject matter to make it into a work of art for others. I felt artistically 'seen' by you, which was so meaningful as in my eyes, you are a true creative spirit. Both of you together, made the perfect team, and I am ever-grateful.

A special thank you to Katy Mccormick. You are a gifted and compassionate space-holder, and surely kept me enrolled in the MFA when the tarmac was so bumpy at first. Your generous office hours and Skype calls, wherein you reminded me who I am and why I came here, were instrumental in birthing my Future Self within the creative womb of Ryerson University.

To my classmates, thanks for walking the most important path with me. You supported me in ways I can't pretend to express. I shared so many things for the first time, because I felt safe with you all. I think we are a cohort for the stars.

To Sam Hiyate, the 'literary angel' and my favourite partner, you've helped make a small dream of mine come true. To tell my story, the one thing I've always wanted to do, but never could. Until now, until meeting you. 


\section{TABLE OF CONTENTS}

Chapter 1: Content 1

Inner Documentary

Western Philosophers on Enlightenment 2

Spirituality and Enlightenment 3

The Supreme Goal of Art 5

Criteria for the Resolution of Trauma 6

$\begin{array}{ll}\text { Narrative Therapy } & 7\end{array}$

$\begin{array}{ll}\text { Chapter 2: Relevance } & 9\end{array}$

Mysticism \& Documentary $\quad 9-13$

Video Art \& Documentary $\quad$ 13-19

Poetic \& Political Documentary $\quad$ 19-20

$\begin{array}{ll}\text { Documentary Beyond Differences } & \text { 20-21 }\end{array}$

$\begin{array}{ll}\text { Chapter 3: Methodology } & 22\end{array}$

$\begin{array}{ll}\text { Inspiration } & 22-24\end{array}$

$\begin{array}{ll}\text { The Future Self in the World } & \text { 24-27 }\end{array}$

Filming, Take One 27

$\begin{array}{lr}\text { Memoir } & 28-29\end{array}$

$\begin{array}{lr}\text { Travel } & 29\end{array}$

$\begin{array}{ll}\text { Equipment } & 30\end{array}$

$\begin{array}{lr}\text { Video Poems } & \text { 31-32 }\end{array}$ 
The Heroine's Journey

$33-35$

Background Footage

Audio recording

$37-38$

Final structure \& Screening Location

Conclusion

41

Bibliography/Mediagraphy

$42-44$ 


\section{CONTENT}

\section{Inner Documentary}

Letters From My Future Self makes art out of my past experience and the mystical vision of a Future Self. In form, it is an experimental documentary film exploring trauma as a creative portal for awakening beauty — as well as forgiveness, compassion, presence, and other graceful attributes. Throughout the creation of this work, I continue to realize my research inquiry, both artistically and academically, of what embodied wholeness is, and how it can be a point of departure for creative expression and ultimately, life. Through telling my story artistically, I realize that I am so much more than my story. Ultimately, Letters From My Future Self is an 'internal documentary'. This work answers the contemporary need for a wider definition of what the documentary genre can embrace, one that considers the depiction of inner terrain as equivalent to the visible world.

The film crescendos from a painful individual lens, into a more poetic philosophy. This thirty-six minute shift of perception is demarcated by a prologue, seven shorts which I am calling 'video poems', and an epilogue. Entirely written and spoken by myself, the monologue records a forced dive into the interior depths of hell and heaven, and then the journey back into the world with a wiser perspective. The tradition of Zen describes the path towards wholeness in a way my film echoes. To summarize; before Zen the mountains are mountains and waters are waters. After that first glimpse into the truth of Zen, mountains are no longer mountains and waters are no 
longer waters. After enlightenment, mountains are once again mountains and waters once again waters. 1

\section{Western Philosophers on Enlightenment}

Ultimately, I'm interested in the connection between an engaged creative practice and inner-awakening. In making art as a legitimate path to self-realization, which is obviously an endeavour far beyond the reach of this film. Yet I strive to use creativity as a spiritual practice. Spirituality being defined as self-realization or enlightenment, rather than anything associated with religion which I consider an externally imposed belief system. In Michel Foucault's 1984 essay What is Enlightenment, based on Immanuel Kant's answer to the question two hundred years earlier, he defines "Enlightenment" as an attitude towards the present moment where one is released from "the status of immaturity." 2 This immaturity does not imply a lack of physical growth, but a "certain state of our will that makes us accept someone else's authority to lead us in areas where the use of reason is called for." 3 Foucault sides with Baudelaire's belief that the only sphere in which one can "face the task of producing himself," is art. ${ }^{4}$ While we are obviously born human, these philosophers state that it takes a creative practice to become human. Foucault even explains how one can stay immature and unenlightened; when "a spiritual director takes the place of our conscience" - when we govern ourselves according to the map of religion

\footnotetext{
1 “Zen Irodalom Zen Literature,” accessed Dec 14, 2018, https://terebess.hu/zen/qingyuan.html.

2 Michel Foucault, "What is Enlightenment," in The Foucault Reader, (New York: Vintage Books, 1984), 34.

${ }^{3}$ Ibid, 34 .

4 Ibid, 42.
} 
instead of observing the territory of our lived experience. ${ }^{5}$ Essentially, I'm using my own challenging and ecstatic lived experiences as the entry point to self-inquiry and freedom.

\section{Spirituality and Enlightenment}

The notion of art as a path to enlightenment, and a keen awareness of the present moment being the gate-less gate to this ripened consciousness, extends far beyond Western philosophers. Author and spiritual teacher Adyashanti writes, "in order to discover our autonomy, we must be free from all external control or influence. If spirituality is to be meaningful, it must deliver us from all forms of dependence — including the dependence on spirituality — and help awaken within us that creative spark which all beings aspire to. For the culmination of spirituality lies not only in discovering our inherent unity and freedom, but also in opening the way for life to express itself through us in a unique and creative way." ${ }^{\prime 6}$ Adyashanti's perspective on spirituality resembles Foucault's understanding of enlightenment. It's not merely about discovering liberation, which is just the doorway of self-realization, but also "an act of courage to be accomplished personally." 7 Enlightenment is awakening to the integration of divinity and humanity.

To be clear, although I'm interested in exploring the relationship between creativity and awakening, this work is in no way a declaration of any grand personal enlightenment. The peak

\footnotetext{
5 Ibid, 34.

6 “True Autonomy," Adyashanti, accessed Dec 3, 2018, https://www.adyashanti.org/index.php?

file=writings_inner\&writingid $=44$.

7 Foucault, "What is Enlightenment," 35.
} 
experiences translated in my project are done so as motivation for me to continue creating — and living, amidst great challenge. For example, breaking through the confines of the human mind and connecting to divine mother and father energies, can correct deficiencies from our physical parents. I want these insights to be recorded and remembered.

When artist, poet, and spiritual leader Sri Chinmoy was asked if a work of art can manifest a higher state of consciousness than the artist himself has actually attained, he responded:

An artist, just like an elevator, can go very high for a fleeting second and create something very high. Then, the next moment, he can drop. But even if he falls as a human being, the thing that he has achieved remains at its original height. Perhaps the artist will never reach that same height in this incarnation again, but his artistic creation remains. When Keats wrote, "A thing of beauty is a joy for ever," he was in a very high consciousness. But did he remain in that consciousness? When you read the whole of Endymion, you see that there are many lines that are not at all good. But the first line is so powerful. He reached that height for a fleeting second and wrote an immortal line, but then he fell down most comfortably and stayed there. But his achievement remains immortal. ${ }^{8}$

While I do not claim to be creating at the level of Keats, I feel the same way about certain lines of my film script. Being creative has begun to resemble, in its positive effects, my spiritual practice and earlier work as a Yoga teacher and Reiki master. Creativity as a spiritual practice ensures a personally significant relationship to the universe - a kinship to the source light. After receiving the poems, their lines revisit me and the subsequent revelation is no less sublime, much like the spiritual mantras of my past. For example, when I am in a unitive state of consciousness, connected to everything within and without, I often hear the line of my first video poem, "that

\footnotetext{
8 Sri Chinmoy, Art's Life and the Soul's Light (New York: Agni Press, 1974), 55.
} 
golden blanket that goes on forever." Or when I can be with a powerful emotion until it is completely transmuted, I hear my epilogue, "I'd rather be a poet, than prove a point."

\section{The Supreme Goal of Art}

When Chinmoy was asked what the supreme goal of art was, he answered "Selfdiscovery, or God-realization, or Life-perfection."9 Note here how Self, God, and Life are used synonymously. Chinmoy also noted markers for a soulful work of art that was created from the inside out. "Even if it just touches you, immediately you feel a sense of illumination in your entire being. It's like a big, surging wave that spreads all around and inundates everything, washing away all impurity. Immediately your being becomes radiant, illumined and totally transformed." 10 Thomas Moore, American psychotherapist, former monk, and author of $A$ Religion of One's Own: A Guide to Creating a Personal Spirituality in a Secular World, agrees with Chinmoy. He writes about the deep purpose of art being a house for spirit. That art, is not merely an expression of the artist but a form of power, that can be transferred to the viewer and offer healing. He goes further suggesting that art can literally absorb particular rays of astronomical bodies and should be revered as these literal presences. While I may never reach this level of transformative and healing artwork, these descriptions on what art can achieve, precisely align with my personal creative philosophy.

\footnotetext{
${ }^{9}$ Sri Chinmoy. Art's Life and the Soul's Light (New York: Agni Press, 1974), 54.

10 Ibid, 34 .
} 


\section{Criteria for the Resolution of Trauma}

The wound from which this creation grows - childhood trauma and complex posttraumatic stress disorder (c-PTSD), is a hugely devastating epidemic. Attention to violence against women is one of the growing themes of our time, with \#MeToo a social media rally cry. As a result, there is a large body of contemporary psychological research in support of how to heal trauma. Although Letters From My Future Self was entirely guided from within, my creative process is in alignment with established and contemporary trauma research. Psychologist Mary Harvey defines seven criteria for the resolution of trauma, and this project mirrors steps four through seven. Actually, steps one through three — bringing physiological symptoms of c-PTSD within manageable limits, bearing uncomfortable feelings, and having authority over memories, were completed in the decade prior to this creative project. The fourth step is when the memories of traumatic events exist in a coherent narrative, linked with feeling. The fifth is when the damaged self-esteem has been restored. The sixth is when a connection to present day life has been reestablished. The final step is when the person has developed a coherent system of meaning and belief that encompasses the story of the trauma.

Step four began as I wrote out my traumatic history and recorded myself reading it aloud. Restoration of self-esteem, step five, came through a connection to my Future Self. With her, I began to access a felt sense of who I had always been, and would also grow into with time. She was me without c-PTSD, with a heart-centred orientation towards life - a continual work in progress. Step six, the restoration of connection, occurred through the visual aspect of this project. I paired my narration in post-production with lush images of elements of nature — air, 
water, earth, birds, myself, and so on, shot as part of an embodied creative practice, recording whatever lit my body up. When we look for beauty, beauty grows. My outer life, through capturing beauty, gradually shifted from prison to playground. The seventh step — making meaning out of the trauma, is evident in the deeply spiritual underpinning throughout this project. The grander insights about forgiveness, compassion, embodiment, letting go, and so on, wouldn't have occurred if I hadn't endured such horrific circumstances, as well as having the privilege of time and money to access and engage with a variety of mainstream and alternative healing methods. Furthermore, I would humbly add an eighth step to Harvey's research sharing the healing insights with others, which I am just beginning through presenting this film.

\section{Narrative Therapy}

Research around personal testimony and narrative therapy is also reflected in this work. Examining the power of writing in resolving trauma is the work of Bessel Van Der Kolk, a world renowned expert psychiatrist working and publishing in the field of post-traumatic stress since the 1970s. His 2014 New York Times best seller, The Body Keeps the Score, has a chapter dedicated to the transformative effects of writing about traumatic experiences. To summarize, individuals who write about the facts and emotions related to their trauma had a fifty percent drop in doctor visits and a more optimistic attitude compared with those who did not. ${ }^{11}$ Studies from all around the world consistently show that writing about upsetting events, although difficult in the short term, eventually improves physical and mental health. ${ }^{12}$ Merely expressing

\footnotetext{
${ }^{11}$ Bessel Van Der Kolk, The Body Keeps the Score (New York: Penguin Group, 2014), 238.

12 Ibid, 241.
} 
trauma, whether it be verbally in talk therapy or physically in somatic based therapy, is not enough. Full vitality requires translating these experiences into language. 13 This was indeed my experience. While documenting my narrative was extremely difficult, each writing session became easier. Upon completion, the content is far more integrated and less difficult to contemplate.

Established scholars are supporting creativity as a way to integrate not only the tragic, but also the transcendent. Thomas Moore, referenced earlier, speaks of the importance of translating mystical experiences into art. Making the intangible, something we see or hear 'on the inside', into something 'tangible', helps synthesize these spiritual insights into our everyday lives. Making art out of our mystical experiences makes practical use of them instead of letting one sublime experience after another pass us by.

I received the content of the video poems while in a meditative state. The lines weren't birthed from the cognitive mind in the same way my memoir was. And I am certain the wisdom contained within the stanzas wouldn't have embedded itself so firmly in my waking consciousness if I hadn't been re-exposed to them again and again in post-production editing. Because of the gravity of the trauma I describe, it has an unfortunate tendency to be the focus of this film. Yet I do convey a complete healing arch wherein tragedy and transcendence are quite balanced. It was important to me that the healing insights received equal documentation. If we look closely, there is adequate grace to counter our challenges.

\footnotetext{
13 Ibid, 243.
} 


\section{RELEVANCE}

Mysticism and Documentary

Letters From My Future Self is predominantly inspired by creators whose objective is to document the mystical. I'm categorizing my work among artists who value the exploration of inner reality as much, if not more than, the outer world.

This work is especially situated among those artists using their practice to cultivate peace amidst very difficult external circumstances. Robert McDowell, author of Poetry As Spiritual Practice, writes how often it is the most difficult situations that prompt an inner communion through artistic means. McDowell references Saint John of the Cross, who discovered art as a way to connect to a transcendent truth while being tortured in prison and apparently was free of anger upon his release. Thematically my work is striking similar chords as Saint Francis'. Here is the final stanza from The Prayer of Saint Francis:

Lord, make me a channel of thy peace, That where there is hatred, I may bring love;

That where there is wrong, I may bring the spirit of forgiveness;

That where there is discord, I may bring harmony;

That where there is error, I may bring truth;

That where there is doubt, I may bring faith;

That where there is despair, I may bring hope;

That where there are shadows, I may bring light;

That where there is sadness, I may bring joy.

Lord, grant that I may seek rather to comfort than be comforted;

To understand, than to be understood;

To love, Than to be loved.

For it is by self-forgetting that one finds.

It is by forgiving that one is forgiven.

It is by dying that one awakens to Eternal Life. 
The lines spoken in several of my video poems also describe transmuting pain into transcendence and shifting one's focus from how one was hurt, to how one can serve. To reference a few from various poems:

yes, you saw how people hurt you

but it means no more than that

they hurt you

forgive them

it costs you, not them

there is no solution, in the content

there is a world, within this world, and it is flying

to see the world as yourself, is to truly see

I was this pure, even during all of that. And so was everyone else.

Although I would not place the writing within my film in the same league as Saint John of the Cross, I certainly do feel as though the difficult situations in my life - because for the most part I went directly through them as opposed to suppressing them, allowed a fresh perspective and creativity to birth. For the most part my film progresses from dark to light, messy to clear, in the non-linear fashion that all human healing arcs travel.

Another spiritually oriented artist I am deeply inspired by is Hildegard of Bingen, the visionary mystic, writer, composer, and abbess, who is considered the founder of scientific natural history in Germany. She also contemplated the relationship between creativity and enlightenment, perceiving that "the Word and God are inseparable." This statement could be translated as; the absolute consciousness, and its finite expression through the human being, are 
one and the same. She composed hymns and wrote poetry that celebrated her relationship and dialogues with the unseen dimension. 14 There is an immense tradition of mystical poetry outside of formal religion, in the likes of Rumi, Hafiz, Kabir, Rilke, Mirabai, and numerous contemporary examples such as David Whyte, Mary Oliver, and Walt Whitman, that establish and celebrate the scared marriage of spirit and matter. The last stanza of Whyte's Everything is Waiting For You comes to mind.

Put down the weight of your aloneness and ease into the conversation. The kettle is singing even as it pours you a drink, the cooking pots have left their arrogant aloofness and seen the good in you at last. All the birds and creatures of the world are unutterably themselves. Everything is waiting for you. ${ }^{15}$

Whyte's "Everything" is one's inner life that reveals itself as having always been there, if only one had the eyes to see it.

Chinmoy, in his book Art's Life and the Soul's Light, writes how the higher planes contain the essence of everything before it is manifested on earth. He writes, "nothing on earth can exist that has not first existed in the inner world. From the formless it takes form on the earth plane."16 An artist whose work evokes a poetically summarized sublime inner cosmology is Hilma Af Klint. Although her work is over a century old, in fall 2018 it showed at the Guggenheim in New York City with an exhibition entitled Paintings for the Future. Although in form her collection of

\footnotetext{
14 Robert McDowell, Poetry As Spiritual Practice (New York: Simon \& Schuster, 2008), 5.

15 “David Whyte,” accessed Dec 3, 2018, http://www.davidwhyte.com/english-poetry/.

16 Sri Chinmoy, Art's Life and the Soul's Light (New York: Agni Press, 1974), 67.
} 
bold, colourful, and radically abstract paintings don't resemble my work, they support my creative impetus. Her paintings were not of exterior worlds and resembled nothing the art world had seen at the time. Perhaps she is documenting the interior realms Chinmoy says exist — the subtle world, before it becomes the world we see. Similarly, the voice and vision of the Future Self is not something I've entirely manifested as a human being. She's an ideal I contacted through spiritual practice that I strive to weave into my lived experience.

Af Klint's biography would support the argument that she was documenting something 'real', although outside the realm of the average human's perceiving bandwidth. She was deeply influenced by spiritualism, theosophy, scientific traditions, and accompanied her art with instructions to not show it until after she died. She felt the world wasn't ready to receive her mystical view of reality, which she envisioned while practicing mediumship. ${ }^{17}$

Excitingly, such spiritual themes are becoming abundant in the contemporary art scene. In 2018 The Rubin Museum in New York City exhibited Three Perspectives on Time, which combines scientific and Buddhist understandings on how we can reimagine our relationship to time.18 Tibetan Buddhism has long been celebrated for its detailed maps of the innumerable levels of human consciousness. The inner worlds have been literally 'documented', though not so much in Western art culture - until now. The video installation, Three Perspectives on Time, combines scientific and Buddhist understandings on how we can reimagine our relationship to

\footnotetext{
17 “Hilma af Klint: Paintings for the Future,” The Guggenheim, accessed Dec 3, 2018, https://www.guggenheim.org/ exhibition/hilma-af-klint.

18 “The Future is Fluid,” The Rubin, accessed Dec 3, 2018, http://rubinmuseum.org/theme/the-future.
} 
time. ${ }^{19}$ It explains how when one attains an enlightened consciousness, all of time is experienced as simultaneous, and thus, the future is accessible now. There is a growing community of artists exploring remarkably similar ideas as I am in my own humble work — such as the feasibility of accessing the voice of a Future Self through realizing the eternal present moment.

\section{$\underline{\text { Video Art \& Documentary }}$}

Bill Viola is the primary video artist inspiring my project because of the extent that he uses his own inner experiences as a prompt and lens to explore evolved consciousness enlightenment, or as Foucault wrote, "a heroization of the present."20 He's very much influenced by his spiritual understandings, inspired by the traditions of Christian mysticism, Zen Buddhism and Sufism. His work has a definite transcendent quality, supported through the advancements of computer imaging and sound technologies supporting an advanced poetic execution. Viola documents the mystical through depicting opposites, or dualities within experience, believing that comprehension of subject cannot be gained unless its opposite is also known. For example, he often places human experiences such as love, next to pain, or birth next to death. ${ }^{21}$ Through these contrasts a humanist spirituality is portrayed. My video poems also contain a mix of opposite human experiences and images, placed directly and quickly next to each other like Viola's yin yang visual/sound equations. For example, from my fourth letter are the lines:

nobody in my family acknowledges my goddam fucking experience I don't know why my life was so hard

\footnotetext{
19 “The Future is Fluid," The Rubin, accessed Dec 3, 2018, http://rubinmuseum.org/theme/the-future.

20 Ibid, 42.

21 “Bill Viola,” Wikipedia, accessed Dec 3, 2018, https://en.wikipedia.org/wiki/Bill_Viola.
} 
what does it mean to die?

but more importantly, come back.

again and again and again

every time I came back stronger and stronger

Viola also shares a definition of spirituality as being more about self-knowledge than associated with formal religion. In a 2011 interview at the Louisiana Museum of Modern Art Viola says, "I keep a constant dialogue with myself. That is the centre of my work."22 Letters From My Future Self was both birthed and continually guided by a freehand morning meditative writing practice. For Viola, his inner world and the images he envisioned there took precedence over his outer reality ever since he nearly drowned at six years old. Nearing death, at the bottom of the lake he saw "the most beautiful world he has ever seen." 23 Even after he was rescued that paradise remained in his mind's eye. Viola considers that world, the real world, and it became his lifelong exploration to continually rediscover it. Similarly, I escaped trauma as a child through leaving my body and escaping into ecstatic spiritual dimensions.

As a result of his pivotal childhood journey, Viola uses water as a recurring motif in his videos, as do I. Art Historian John Wash specifically highlights the use of water in Five Angels for the Millennium (2001), as playing a significant role in expressing Viola's spiritual views by evoking "a luminous void of unknown dimensions where the laws of physics seem suspended and the borders between the infinite cosmos and the finite human body merge."24 Presumably

\footnotetext{
22 “Bill Viola Interview: Cameras are Soul Keepers," video, 28:09, https://www.youtube.com/watch? $\mathrm{v}=$ uenrts2YHdI\&t$=2 \mathrm{~s}$.

23 "Bill Viola Interview: Cameras are Soul Keepers."

24 “Bill Viola Five Angels for the Millennium 2001," Tate, accessed Dec 3, 2018, https:/www.tate.org.uk/art/ artworks/viola-five-angels-for-the-millennium-t11805.
} 
this is what Viola experienced during his near death experience and his subsequent deep dive into the direct-experience of mystical traditions. My attachment to water imagery as well comes from the feeling that water best represents and evokes the eternal, mysterious flow of existence.

Five Angels for the Millennium comprises five videos, individually titled Departing Angel, Birth Angel, Fire Angel, Ascending Angel, and Creation Angel, that are projected onto the walls of a dark gallery space. Each video features a slow motion clothed male figure in varying colours rising out of, plunging into, and hovering over a pool of water. Each video has an accompanying audio track that gradually crescendos as the figure emerges from the water. Similarly, my work also contains images of me jumping in and out of large bodies of water, in slow motion. One could postulate by the work's title and the way Viola combines image and sound that he is inviting an emotional reflection on the evolution of spirituality, a dialogue I am also interested in..$^{25} \mathrm{He}$ has said how Five Angels for the Millennium produces

an enveloping emotional experience like that of a church. I guess the connection ultimately has to do with an acknowledgement or awareness or recognition that there is something above, beyond, below, beneath what's in front of our eyes, what our daily life is focused on. There's another dimension that you just know is there, that can be a source of real knowledge, and the quest for connecting with that and identifying that is the whole impetus for me to cultivate these experiences and to make my work. And, on a larger scale, it is also the driving force behind all religious endeavours. There is an unseen world out there and we are living in it. 26

Viola is demonstrating the lived experience of self-realization. Enlightenment is often described as the ocean that fish (our egos), are simultaneously swimming in, and literally are, at all times.

\footnotetext{
${ }^{25}$ Ibid.

26 Ibid.
} 
Another work of Viola's that demonstrates how he uses his artist practice to "face the task of producing himself'27 like Baudelaire proposed only art could, is Nantes Triptych (1992). This video installation project began as Viola's innocent and heartfelt desire to understand what was actually happening to his mother as he observed her slowly dying. He decided to record the process on his video camera in order to meditate on it at a later date. Although he wasn't taking video when life left her body, he did document her final weeks. As part of his healing process, he watched the footage every morning “as a kind of prayer. She was there, she wasn't there. It was all equal.”28 As Viola's organic self-inquiry, akin to the well-known Zen Koan 'what was your face before you were born' progressed, he had a life-changing revelation. "My life, my family, going the zoo, playing football with my kids, going to the beach, is equal to making a piece for the Guggenheim. If you're going to make art it has to be one thing. You can't be mister famous artist here and something else there. You can't keep those things apart if you want to live life to the fullest."29

Nantes Triptych exemplifies Viola's epiphany that all of life's varying currents are essentially equal, through placing the video footage of his mother on the right, his first son being born on the left, and the journey between birth and death in the centre, represented by a body floating in water. Through his artistic practice, through taking the video of his mother and

\footnotetext{
27 Foucault, "What is Enlightenment," 41.

28 "Bill Viola Interview: Cameras are Soul Keepers."

29 "Bill Viola Interview: Cameras are Soul Keepers."
} 
working with it daily, Viola attained a greater level of enlightenment. He was able to perceive the mysterious web that links all flavours of human experience, form ecstatic to mundane.

I consider my prologue, the minute and a half clip of me reading the effects of severe trauma, similar to Viola's relationship to the footage he shot of his dying mother. Every time we mindfully observe what we consider the farthest thing from comfortable, an intimacy with fear develops. Enlightened consciousness is never separate from anything it perceives. A truly awakened heart can hold it all, with compassion. What we push away costs us our connection to life. So when we meditate on that which saddens us the most — for Viola it was losing his mother, for me it was my lost childhood — there is an opportunity for greater wholeness.

Like myself, Viola believes that artistic images have transformative powers within the self. The powerful images he displays of birth and death are not intended as mysteries to be solved - which he criticizes Western science-oriented culture for, but mysteries to be experienced and inhabited, which evokes their powerful emotional and spiritual effects. ${ }^{30} \mathrm{He}$ critiques the loss of an inhabited spirituality within contemporary society, and strives to encourage these experiences through this artwork. Similarly, Letters From My Future Self does not provide answers, or tell anyone's story or perspective but my own. This film documents my journey of growing autonomy as I move in the world, while wrestling with troubling personal matters. I offer the creative response that brought me solace. I have not, and may never, figure

\footnotetext{
30 "Bill Viola Nantes Triptych 1992," Tate, accessed Dec 3, 2018,
} https://www.tate.org.uk/art/artworks/viola-nantes-triptych-t06854. 
out how to totally heal from c-PTSD or attain complete spiritual embodiment, but I do feel, like Viola, that I am wholeheartedly exploring this territory.

I'd also situate my project alongside Swiss artist Pipilotti Rist, considered a worldrenowned pioneer in video art. Words commonly used to describe her work are; surreal, intimate, abstract, feminist, and self-portrait. I'm most interested in her work, Pour Your Body Out (2009), installed at the Museum of Modern Art. Here she explores an idea central to Letters From My Future Self, that of conscious and creative embodiment, the realization of spirit as an individual human body. In this piece she is working to dispel the notion that transcendence is good and the body is bad. She's interested in what happens when we bring light and matter together. A turning point in my own life was when I realized I could not 'go up' for the light anymore. In my autobiographical film script I write, "That morning meditating by the lake, the aperture of my consciousness exploded open, but I hadn’t landed.” My elevated insights were needed for my own tangible and practical life. I write, "I still connected to the golden light every day, but not to escape violence, just to improve my life."

Visually, Rist's intention is to represent what we actually see, as clearly as possible. For this, she uses the latest technology to capture video. I as well, am shooting $4 \mathrm{k}$ video on the Go Pro 6 and iPhone 7. We also are both drawn to nature, and the holiness of water specifically. Another Rist piece, 4th Floor to Mildness (2016), is composed of underwater gas bubbles. Half of my water shots are underneath the surface. At the core Rist is interested in discovering beauty and love - in yourself and others, which is the strongest thematic undercurrent of my work. I 
write about a peak experience meditating by the lake where I realized "It's all love, trying to figure out, that it's all love."

\section{$\underline{\text { Poetic \& Political Documentary }}$}

Creating an inspiring artistic documentary is poet and filmmaker Forough Farrokhzad, in her only film, The House Is Black. She was the first woman in Persia to write about her own volatile life, including her sexual desires. She was equal parts potent political figure, goddess, and martyr, largely reviled by the press as a whore and dismissed from the literary canon. ${ }^{31}$ The House Is Black, is at first glance a sensitive portrayal of the suffering in a leper colony. Beyond this, the film functions as a metaphor for how Farrokhzad viewed her homeland. Iran had become stagnant, inert, and spiritually dead.32

Despite its direct critique of religion, the film was not banned. It succeeded, both in social critique and as a piece of art, because Farrokhzad was responding to her world "through the art of the interior." 33 Farrokhzad has said that "what matters, is to cultivate and nourish one's own positive characteristics until one reaches a level worthy of being a human. What is important is the work produced by a human being and not one labeled as a man or a woman. When a poem reaches a certain level of maturation, it separates itself from its creator and connects to a world

\footnotetext{
31 "Radical Humanism and the Coexistence of Film and Poetry in THE HOUSE IS BLACK," Jonathan Rosenbaum, accessed Dec 3, 2018, http://www.jonathanrosenbaum.net/2001/04/tradical-humanism-and-the-coexistence-of-filmand-poetry-in-the-house-is-black/.

32 Roxanne Varzi, "Pictura Poesis: The interplay of poetry, image and ethnography in Forough Farrokhzad's The House is Black," Off Screen 18, Iss. 9 (2014), https://offscreen.com/view/house-is-black.

33 Varzi, "Pictura Poesis," Off Screen 18, Iss. 9.
} 
where it is valid based on its own merits." ${ }^{34}$ Again we have a perspective similar to Baudelaire of how art can "liberate man in his own being" allowing him to "face the task of producing himself."'35

As I documented my history, I realized that all these terrible and transcendent experiences, were all who I was not. I was writing myself into a whole new life. Although I'm doing a personal work, my hope is that my film can function separately from myself, as a template for another's successful journey within and without. It's fair to claim that everyone has been traumatized at some point, in some way. By being artfully transparent about my own experiences, I'm hoping to add to the contemporary conversation around resolving our collective traumas. For myself, like Farrokhzad, the poetic becomes political.

\section{Documentary Beyond Differences}

I have chosen to group my work amongst artists who prioritize their inner life. This shift in consciousness and revival of spirituality is really the call of the times. A society of selfrealized individuals don't require babysitting. Thus, the ways of enlightenment should be reflected in documentary practices, rather than our current climate, highly concerned with honouring our differences (think, 'identity politics'). And while there is a crucial place for noting distinctions, there must also be a place for art to support the 'mature' individual Kant proposed, one free of unquestioned constraint. May we all look within and create without, in a manner

\footnotetext{
34 "Forough Farrokhad," Wikipedia.

35 Foucault, "What is Enlightenment," 49.
} 
perhaps best summarized by renowned Canadian pianist Glenn Gould. "I believe that the justification of art is the internal combustion it ignites in the hearts of men and not its shallow, externalized, public manifestations. The purpose of art is not the release of a momentary ejection of adrenaline, but is rather the gradual lifelong construction of a state of wonder and serenity." 36

36 Geoffrey Payzant, Glenn Gould Music \& Mind, (Toronto: Key Porter Books, 2005), 64. 


\section{METHODOLOGY}

$\underline{\text { Inspiration }}$

The research for my experimental documentary film, Letters From My Future Self, originated with my several decade personal journey of healing from severe childhood trauma and its negative consequences, which persisted into adulthood. The necessary therapeutic exploration included thousands of hours of mainstream and alternative healing modalities, culminating in a spiritual awakening at twenty-seven years old during 2010, where I remembered intrinsic wholeness, after which I positioned myself as a healer and teacher. Until, for various reasons, I could no longer do either. I felt a strong call from within to create video art more seriously, which I hadn't done for years since my undergraduate film degree.

Although I had attained a remarkable level of psychological stability considering my difficult upbringing, I was not satisfied with the still-lingering ramifications of complex posttraumatic stress disorder. Because my body wasn't safe, I developed an advanced understanding of ethereal spiritual reality. This knowledge served me as a Reiki energy healer, but day-to-day mundane matters remained challenging. Remembering my creative life seemed to be the evolution of my grounded spiritual journey, which now had to include my individual, along with my universal self. Could a creative practice nurture the further embodiment I sought? I wanted to express the gold I'd discovered within, through significantly coming to terms with my violent life experiences, not through serving others energetically as a holistic therapist — but through sharing these realizations in a film. 
The notion of the Future Self is not conceptual, but rather, envisioned and birthed from a deep meditative space. She first appeared in 2016 while working with clients receiving bodywork on my treatment table. I would witness, with my inner eye, their future selves. They appeared exactly the same, except without physical or psychological restrictions. I observed their overall health, as pure potential — essentially perfect. At this point in the session, an energetic resonance would occur whereby the Future Self would transfer healing to the client on the treatment table. To my astonishment, clients' various situations improved. I had studied many kinds of subtle bodywork up until this time — Reiki, Thai Yoga Massage, Shiatsu, Medical Intuition, and Palliative care, yet this 'technique', which was not learned from anyone else, was remarkably effective.

On the suggestion of my partner, I began communicating with my own Future Self. I spent the last ten minutes of my seated meditations energetically merging with her. I would visualize her body filling up my body until I felt like I was looking through her eyes, until I felt like I essential was her. I also journaled three hand written pages every morning, asking 'her' questions and listening for 'her' answers. Both of these endeavours yielded positive results in my life physically, emotionally, and spiritually. Similar to my experience when offering therapy to others, unlike the myriad of therapeutic approaches I had previously used to help myself, which all had their place in time, it appeared as though this technique had particular power because it was internally sourced. My Future Self was not an external guru but simply my wondrous, perfected self, reaching back in time, teaching me how to move from Truth. She was a bridge 
between universal divinity and imperfect individuality. Looking back, her introduction to my life certainly did mark the beginning of my journey into embodied wholeness.

I experienced several powerful dreams that indicated this methodology — of listening to and ultimately becoming my Future Self — was not a spiritual cul-de-sac, but a personal and artistic path of self-discovery and spiritual integration. I also discussed this developing inner process with a trusted mentor, international spiritual teacher Jac O'Keeffe, who described the Future Self to me.

It's a great model to anchor in your own automatous viewing point. It's giving you an anchor that's not from the external world. It's a story, where you go deeper into your own pure vision. The Future Self is a consolidated version of how I see you. More whole. The Future Self doesn't experience the rattling that your traumatized self does. It could be 'God', but for you, it's your Future Self. She's a fantastic crutch. When she's not there, you'll know that you're her, but you're not awake enough to sustain that all of the time. You are not perpetuating the dualistic realm by connecting with her. She is not yet being used by your mind to keep duality going. ${ }^{37}$

Discussing the Future Self with Jac O'Keeffe, and having her encouragement, dramatically increased my self-trust and motivation to move forward with these inner insights.

\section{The Future Self in the World}

As these self-designed journalling and meditation practices gained regular momentum, I began seeing numerous reflections of the Future Self in the outside world. Renowned addiction and trauma expert Dr. Gabor Maté recently teamed up with Kundalini yoga teacher and Naturopathic Doctor Sat Dharam Kaur, to create Beyond Addiction, an internationally recognized

37 "Future Self with Jac and Tara," Vimeo unlisted video, 22:49, posted by "GOTEAMLIGHT," March 2018, https:// vimeo.com/258968116/3ef23e025b. 
sixteen module course to "support individuals in establishing healthy thought patterns and behaviours to nourish mind, body, and spirit and manifest an inspired and fulfilling life." 38 One of the classes is labelled Your Best Future Self, and is described as follows:

Your addiction is not you. It does not define you. You are someone who exists in relationship to a substance or behaviour. Deep down you are still you. This we call the true self, higher self, soul or spirit. One way to reclaim your true self is to create a relationship with your Best Future Self. The potential of who you are and can be is always calling you, inviting you to fully manifest your essence and destiny. 39

Maté and Kaur's extensively researched treatment approach is supported by the amply demonstrated theory within quantum physics of how the future can influence the past. 40 This is how connecting to our best Future Self can positively change our present reality.

The next significant synchronicity of coming across the Future Self in the world occurred through the work of psychologist and International meditation teacher Dr. Tara Brach, whose work blends Western psychology and Eastern spiritual practices. Just after I had discovered my own Future Self, purely through intuitive means, she was simultaneously releasing Future Self therapeutic tools with a remarkably similar philosophical underpinning and methodology. In a 2016 lecture Brach speaks of the Future Self.

Our Future Self is the most evolved expression of who we are. It is how awake loving presence lives through this body and mind when it is fully manifested. If you prefer other language it's your highest self or your true self. So we begin by visualizing our being

\footnotetext{
38 “Beyond Addiction," accessed Mar 22, 2019, http://beyondaddiction.ca/about.

39 “Lotus Yoga,” accessed Mar 22, 2019, https://www.lotusyogacentre.com/addiction-workshop-jan-2019/.

40 "Quantum Theory Predicts that the Future Could Be Influencing the Past (yes you read that correctly)," accessed Mar 24, 2018, http://www.collective-evolution.com/2017/09/19/quantum-theory-predicts-that-the-future-could-beinfluencing-the-past-yes-you-read-that-correctly/.
} 
when we are really manifesting love and presence. How does your more evolved being appear? What are they wearing? How does this express something about you? But most of all, sense how your Future Self's wisdom expresses through the eyes, face, posture, and hands. See if you can sense energetically your own being when your heart is really awake. You can now explore bringing a current life challenge to your Future Self. Maybe something that is difficult or hard to forgive. Or a fear, struggle, or loss. You're bringing this to your Future Self for guidance and healing. Be open to the words or energetic response from your Future Self. Allow your Future Self's presence to fill you. Notice how your body feels. Sense the expression on your own face, when you are manifesting an awakened heart. ${ }^{41}$

It seemed as though I was not the only one gaining confidence in the merits of contacting a healed and whole Future Self through meditative envisioning and inquiry. Although I did briefly involve myself in Brach's guided meditations and the Beyond Addiction Future Self module, I quickly decided to not source my process through any external means, despite the remarkable similarities in approach. It was important to me that my own intuition guided this exploration. This self-trust was challenging, as these teachers and researchers have extensive experience and accolades in the therapeutic industry. But I steadfastly honoured the notion that her voice had to exclusively emerge from within, despite the outside echoes. I considered these external mirrors a wink of encouragement for my own unfolding, versus something outside myself I should align with.

Research led by intuition is a legitimate methodology within Indigenous Research Methods. Furthermore, Indigenous Research Methods propose that the garnered insights should not simply accumulate as a pile of abstract research findings, but should be fully internalized and

\footnotetext{
41 "Future Self with Jac and Tara," Vimeo unlisted video, 22:49, posted by "GOTEAMLIGHT," March 2018, https:// vimeo.com/258968116/3ef23e025b.
} 
lived. Author Shawn Wilson writes how "during this internalization, the relationship between the beliefs and the person starts to gain its strength." 42 My relationship with the Future Self was becoming so much more than a creative exercise, but the guiding light in my life. Every day I worked with her energy in my meditation and writing practices. I tried my best to follow all of her instructions - from the most important tasks to complete, relationships to foster, and inner points of concentration such as gratitude, presence, and kindness. As a result, stubborn and reoccurring c-PTSD symptoms began to diminish. I started sensing a life beyond being a wounded healer — albeit successful and still fulfilling on many levels, in a holistic clinic. In 2017 I was guided to apply to an MFA program and turn my autobiography into a piece of art. While I did not feel my life was worthy of an autobiography, I felt there was enough raw material, that if transmuted, could inspire a film to benefit myself and hopefully others. Yet I was totally unsure of how.

\section{Filming, Take One}

My attempts to actualize a film began by recording video of myself reading my morning journals, as well as meditating. However, because I was writing and sitting every day, I was rapidly accumulating a large volume of video footage that I also couldn't stomach to preview! A large part of the dialogue involved me verbalizing personal dilemmas, seemingly ad nauseam, and the meditation footage often displayed me releasing deeply buried subconscious emotions. I felt like the most important part of the Future Self's techniques wasn't documenting them in their entirety, but following through on the insights. Primary to my Future Self's guidance at this time

\footnotetext{
42 Shawn Wilson, "What is Indigenous Research Methodology," Canadian Journal of Native Education 25, no. 2
} (2001): 178. 
was to begin typing my life story, from start to finish. I began this process with discipline in spring of 2018 as the first year of the MFA concluded.

\section{$\underline{\text { Memoir }}$}

To assist my writing process was my partner and literary agent, Sam Hiyate. Sam teaches creative writing at the University of Toronto and publishing at Ryerson. His specialties are memoir and literature and I have witnessed him transform personal stories into books of international relevance. Interestingly, while I have been making videos for over a decade, I'd also already been writing in word files with a count far exceeding a million words. I always thought that if I could make something powerfully tangible — and ideally sublime, out of what happened to me, then it would have more value. Other prominent writers and journalists have wanted to share aspects of my narrative before, but I always knew it was my story to tell. I'd been attempting to communicate my story for a long time — in a highly disorganized and fragmented fashion due to the difficulty of the undertaking. I knew I had to start this writing from scratch, from my current stage of evolution and understanding, and Sam was open to supporting me in this process. Though the majority of his help was reading my latest draft every week and simply encouraging me to 'keep writing'.

Going back into my own traumatic history was more difficult than expected. I found I could not write for more than one hour at a time, and not more than two hours total in the day. I had to practice yoga asana before I started writing to at least begin the process from an embodied place. After the day's writing, I was so dissociated that it would take me a few hours to feel like 
my 'functional 2018' Ashleigh. Because it was so uncomfortable, I often felt that this autobiographical writing project was a terrible endeavour, but I continued because my Future Self inquiry practices revealed that this writing was a crucial stepping stone in the larger art project. As the weeks passed, though never pleasurable, this personal writing became slightly easier and in three months, I had condensed my life into a fifty-thousand word document. But I still had no idea how to make what was essentially a book, into a film.

$\underline{\text { Travel }}$

Furthermore, all the historical excavation took a major toll on my creative fire. None of the events I was writing about were happening anymore, and the present moment is the source of creativity. To help get my mojo back, my Future Self guided me to accompany Sam on an upcoming work trip across Western Canada in August of 2018. I hoped that being away from my familiar surroundings and distractions would further strengthen her voice and vision and reap clarity on the next steps towards making a film. At this time I heard the Mary Oliver poem, "The Journey," which mirrored this internal insight.

But little by little, as you left their voice behind, the stars began to burn through sheets of clouds, and there was a new voice which you slowly recognized as your own, that kept you company as you strode deeper and deeper into the world, determined to do the only thing you could do determined to save 
the only life that you could save. ${ }^{43}$

Also, because water imagery is so prominent in my videos, on a practical level I thought in the very least I could retrieve useful footage of ocean waves.

\section{$\underline{\text { Equipment }}$}

Another big decision at this time was deciding what camera equipment to travel with. Up until this point, I had been shooting most of my projects with a GoPro or iPhone, though admittedly had a little bit of shame around this decision, always doubting whether I was sacrificing a more refined aesthetic. However, because a large part of the research fuelling this film concerned 'embodied wholeness', it was actually very important that my equipment support this embodied creative practice. Using the least cumbersome technology as possible deeply supported my instinctive and quiet-minded way of capturing images. So I packed only cameras that fit in the palm of my hand, with few technical settings beyond 'off' and 'on'.

As we moved from city to city, I began collecting fresh, uncontrived, and spontaneous moving images — mostly of nature; air, water, earth, birds, myself, and so on — shot in an embodied way. I believe travelling supports embodiment as it involves a continual changing of the outward reality, therefore encouraging one to orient internally. Throughout this month of changing locations, my small cameras were always on hand. I would wait for my vision to arrest me into an experience of unity. These matters are difficult to put into words. When you witness

\footnotetext{
43 “Mary Oliver, The Journey,” accessed Mar 22, 2019, http://www.phys.unm.edu/ tw/fas/yits/archive/ oliver_thejourney.html.
} 
something other than you, as something also arising within yourself, it's a beautiful moment, and I strove to record it. Unfortunately this does downgrade the direct experience of connection — 'a finger pointing to the moon is not the same as the moon itself', yet I had an art project to complete!

I was striving to capture the mystical vision summarized extremely eloquently by German philosopher and mystic Meister Eckhart, "the eye with which I see God is the same with which God sees me. My eye and God's eye is one eye, and one sight, and one knowledge, and one love." 44 Through intuitively tuning into the sublime forms popping through this moment, I was growing an ability to see reality as it is without the interference of the mind, which tends to hijack direct experience and shield omnipresent beauty.

\section{$\underline{\text { Video Poems }}$}

The greatest success of this trip occurred when the voice of my Future Self evolved beyond the pages of my morning journalling into an internalized voice that felt even more like my own. Not my 'small self', but the part of me that is rooted in silence. I always heard my Future Self's voice when my entire being was still. Her intuitions first arose through poetry. I would hear one line at a time, and each poem was around ten lines. I always knew when the last line of the poem had been delivered. She was communicating healing insights about how to perceive my past. How to forgive and let go. Never before had my creative practice felt so guided, so intimate, and yet, so much larger than me. In my morning journalling I was instructed

44 “Meister Eckhart,” accessed Mar 22, 2019, https://en.wikiquote.org/wiki/Meister_Eckhart. 
to combine the microcinema moving images with audio of myself reading the poetry into my iPhone microphone. I found that the images were a remarkable match to the ideas I was exploring through language. As the second year of the MFA began in fall of 2018, I had completed seven 'video poems', each under one minute in duration.

Unlike the writing of my historical narrative, I truly loved the process of making these shorter videos. They were helping me integrate my past and fall in love with my here and now life, and self. As my creative point of departure evolved from yesterday to now, my time making art began to feel like my most relevant spiritual practice. This film, especially the video poems and epilogue, are the closest I have come to expressing part of my artist statement of 'making art out of my mystical visions to reach a state of embodied wholeness.' This work has carved an entirely new artistic track for me that I hope to continue in the years to come.

With the completion of the seven poems, I had to return to the longer narrative. I needed to create a script $5 \%$ the length of what I had currently written, in order to make a film within respectable time limits. I ruthlessly edited my memoir for several months. The goal was to turn my history, which in many ways resembled a horror movie, into a source of empowerment instead of dismay, even distilling down the core movements enough so that others could receive as well. We can't change what happened, but we can choose how the story moves from here. 


\section{The Heroine's Journey}

Even though this is technically my story, I wanted it to function as a universal map akin to psychotherapist and author Maureen Murdock's The Heroine's Journey. The Heroine's Journey is the female equivalent of Joseph Campbell's well-known story template, The Hero's Journey. The feminine battle being understood as more internal, involving the greater search for self. ${ }^{45}$ In order to cut 50000 words into approximately 2500 words, I highlighted the essential movements within Murdock's story template. The Heroine's Journey begins with a separation from the feminine and ends with the integration of the masculine and feminine, with several significant advances in between these milestones.46 I noted these stages in my own life.

For example, separation from the Feminine/Being/Essence occurred quite early in my life. I was born into extreme privilege — and extreme violence and abuse. I was never 'seen', and it was never safe for me to 'just be'. I began attacking my body at five years old, starting with dieting and moving into serious eating disorders and self-harm. One of my brothers was running a massive drug operation on our estate and the other was attempting suicide with the guns my father kept under his bed, which my father often threatened to kill us all with. As a result, I became overly identified with Murdock's 'masculine principle'. I became a superachiever. I was a competitive equestrian, first violin in concert orchestra, and attended Queen's University on scholarship to study neuroscience and astrophysics. I also learned how to leave my body to escape pain.

\footnotetext{
45 Maureen Murdock, “The Heroine's Journey,” Maureen Murdock, accessed April 21 2018, http:// www.maureenmurdock.com/articles/articles-the-heroines-journey/. 46 Ibid.
} 
The Heroine's Journey involves many deaths and rebirths — when we realize we are off the path our soul intended and ideally are awake enough to hear the call back into universal flow. In University I attended a life drawing class. I felt reborn. I switched my major to film. I found and soon taught Yoga and Reiki. Murdock outlines that we always receive tests on our wisdom and realizations. Even though I attained profound insights about what true healing entails, and apprenticed with several respected teachers who said I could teach their system, I hadn't spiritually landed in my body because I hadn't fully processed the depths of my traumas on a physical and feeling level. Deep down I felt like I was helping everybody else — but me. I was still experiencing flashbacks and nightmares. Meeting 'The Goddess' is the most pivotal movement within The Heroin's Journey. In my story, this is when I met my Future Self.

Ideally, the inner gifts that result from our adventures within, serve not just the individual, but the collective. Although I suspect I will go through several more cycles of the Heroine's Journey on the expanding spiral of life, my offering on this round is humbly this experimental documentary film. The public presentation of this film represents a particular completion. The story of my life is no longer an exterior dragon tearing me away from peace without warning. It is now something that I wrote, and shared, with a certain mindfulness.

I wanted Letters From My Future Self to be a visual healing container, wherein viewers could personally resonate with the holistic view of the characters. While constructed from my own experience, the goal is helping others. It's an offering to the feminine principle, which we all 
need to integrate despite our sexual orientation, along with an offering in transmuting trauma, which we've all experienced in some way. For this reason, I left out many details, which comprised a large percentage of the original writing content. Also, many unfortunate life experiences surrounding consent happened again and again until I 'learned the lesson' and created a boundary. I only needed to include one example of a repeated mishap in the final film. These editorial decisions shortened the script.

\section{$\underline{\text { Background Footage }}$}

Once I had polished the script I haphazardly paired it with a relatively unedited back and white shot of the Pacific ocean shore shot at 240fps during my August trip to the west coast of Canada. Although this was originally intended as a place holder until I found images more reflective of the script, myself and those I showed this early cut to, appreciated the blank canvas nature of the slowly evolving waves. Anything more complicated would distract from the powerful narrative. Furthermore, due to the slow motion, a meditative and hypnotic quality was evoked. One begins to see what they need so see, similar to the philosophy behind the psychological Rorschach test. The slowly shifting grey scale image, played at $10 \%$ its original speed, gradually changes in ways that hold our attention to the film, but also allow a visual 'out' if the narrated voiceover becomes too intense. It was preventing the possibility of overly traumatizing the viewer. I also appreciated the symbolic nature of the ocean, sun, and sky. While not literally illustrating what I was speaking about, these images do reflect the themes I am exploring — what is conscious, unconscious, in and out of flow, dark, and light. 
Yet I continued to struggle with not including autobiographical video material of my life, mostly because it already existed in abundance. I had a folder on my desktop filled with old videos and photographs of my childhood, teen years, and twenties — all the periods I was writing about. I could literally illustrate this narrative. My father also resurfaced, after having no contact for decades, and thus I had the opportunity to perhaps include him in the film. After much thought, and nervous system disturbance, I decided to keep the vision of the film through the eyes of the Future Self. I would not overly literalize it. Letters From My Future Self is not art therapy as it is typically known - an exorcism of darkness. My project is about transmutation, about finding wholeness through a fundamental change in our relationship to life.

I did not want to create another conventional 'trauma documentary' supported through home video. I wanted to create a film that was a continuation of works that explore difficult subject matter through beauty and illumination. At the core of this project is the relationship between suffering and grace, how traumatic experiences can awaken the very qualities necessary to heal its effects. Our wounding is our portal to embodied wholeness.

I then came across the work of revolutionary trauma psychologist Dr. Peter Levine, author of Healing Trauma: Waking the Tiger. He writes, "I have come to the conclusion that human beings are born with an innate capacity to triumph over trauma. I believe not only that trauma is curable, but that the healing process can be a catalyst for profound awakening - a portal opening to emotional and genuine spiritual transformation." ${ }^{47}$ This film strives to portray

47 Peter Levine, “Good Reads," accessed May 7, 2019, https://www.goodreads.com/author/quotes/ 142956.Peter_A_Levine. 
the way out of abuse, into the present moment. Thus the final line in the epilogue and really my 'ultimate thesis'; "I'd rather be a poet, than prove a point." I do not intend to glorify the violence or the mystical experiences, but this present moment in which all these states rise and fall.

\section{Audio recording}

Another choice-point with the narrative component of the film was the meditative, nonreactive tone with which I described quite horrifying experiences. I was concerned the audience would think I wasn't telling the truth, or they wouldn't be able to access the intensity of the story through my composure. I contacted a local somatic therapist, trained in Peter Levine's 'Somatic Experiencing'. SE is an embodied form of psychotherapy, meaning sensations in the body are tracked while traumatic events are recalled, helping the client release the emotions tied to traumatic events which have been long trapped in the body. I hoped reading my narrative to a SE practitioner would provide a more emotional reading. This would be very unlike my previous recordings which were completed in my home office after meditating, carefully monitoring my tone and delivery, purposely trying to read as my Future Self.

Recording in front of (trusted) stranger, inputting opinions throughout, while evoking emotions, turned out to be a disaster. Everything that could go wrong on that day, did. Malfunctioning Uber trips, construction outside the recording room, and my own energetic upheaval. I lost a day of productivity due to a massively upset nervous system. These were not new emotional releases - I've done years of therapy on my story. I was flat out being retraumatized, aggressively digging up wounds that had already been seen. 
Because I'd put the effort in however, I did preview this new recording to others, who thankfully preferred the more composed reading. I received the astute comment that witnessing my emotion forced them into my journey, versus keeping the piece an internal experience for them, which was always my primary intention. I also heard that although the reading with more emotion did evoke more emotion in the audience, likely due to mirror neurons, it wasn't as if the meditative reading did not. The latter just encouraged a more contained reflection. I certainly did not want to ignite unexpected distress in any viewer. And on a sentimental level, I didn't want to involve other therapists in my final creative work. This project was about becoming my own therapist, and therefore its internal strategies should come from myself exclusively. When I went inside, I felt there was nothing inherently wrong, and perhaps everything sincerely right, about reading my story from presence in an energetically aware space. The integration of my own trauma would be communicated, versus the sorrow of it. I resolved to keep this project a solo endeavour, speaking the details to myself from the comfort of my own home and heart.

\section{Final Structure \& Screening Location}

In the final term of the MFA, I was still unsure of the structure of the film. I felt the meditative narrative with the waves was basically a complete piece. I also felt the video poems, when played sequentially, were something in and of themselves. I knew I had leeway with my final structure as I had classified this project as an 'experimental documentary'. I received the feedback that the narrative gave the poems more context, that they belonged together in their own unique way. Viewers could recall the experiences I was pointing to within the lines of my poems. Therefore, I felt the narrative should precede the poems. The poems were also an 
evolution, and resolution, to the narrative, showing healing and flowing forward movement. And they were obviously linked by the same voice reading them. I received feedback that one video poem in particular, "that golden blanket," could set up the entire narrative. Here, two Ashleighs talk to each other, specifically about the need to tell the story.

Another debate occurring in the final term of my MFA was whether to show this film in a gallery or theatre. I decided on a gallery. To show it within the various perceived constraints of our graduating DocNow festival (duration, audience, programming etc.), I would have to remove too many important parts from the film. I wanted adequate artistic freedom, so the idea of creating my own theatre within a gallery space, was attractive. Also, because of the sensitive and intense content, I wanted the viewing of my film to be a very mindful and deliberate decision, a task easier to accomplish in a gallery. Once I found my exhibition space, a small dark carpeted room, I felt an unforeseen permission and encouragement to include one small piece of autobiographical material that would contribute to the film I wanted to make - a healing experience for myself and others.

Several years ago, in 2015, well before the notion of doing an MFA emerged, I recorded myself reading a legal letter my therapist wrote regarding the effects c-PTSD was having on my life. At the time it was filmed, I could only read the document to a camera. I shared it with nobody I knew personally. I couldn’t even watch the recording myself, yet it remained on my desktop, waiting for something. I used this clip in one of my first year production classes but edited it to such an extent that it was unrecognizable. But by the end of my second year I felt 
ready to present it to the public, without additional editing. I think the previous year of working with my extended narrative had encouraged enough disidentification to finally work with this shorter clip constructively.

The Heroine's Journey always begins by exposing the problem seeking resolution. This clip accomplishes the impact of the wound within a minute and a half. Although emotionally vulnerable, I don't detail any specifics of the abuse, so the piece remains a template of relative wounding. With its inclusion, we are immediately confronted with the stakes our heroine, i.e me, must confront.

'Past letter from my therapist' is akin to Leonard Cohen's famous song lyric, 'the crack in which the light gets in'. The healing light of awareness, which the remainder of the film is created from, entered through my wound of childhood abuse. I did not begin my journey of living from a place of embodied wholeness until I faced the reality of my trauma. We all have our 'cross to bear', to bring forth, before we can embark on the inward journey of self-discovery which the film gradually traverses. I present myself as the archetypal heroine who is bringing her secrets into the light, rather than keeping them dark and repressed. I open with my unguarded suffering in the hopes that others can come forward with their own personal stories of hurt, through which their always-whole universal selves can be remembered. 


\section{CONCLUSION}

Through my formal and lived research inquiry into embodied wholeness, I have discovered that this grounded inward journey cannot happen exclusively through the light. Our personal mind, body, and story, require illumination. As C.G. Jung said, “one does not become enlightened by imagining figures of light, but by making the darkness conscious." ${ }^{48}$ His realization was reflected in my "born of demons, birthing stars" letter, where I reflect on the unsustainability of spiritual bypassing. However blissful and insightful my initial experience of being "the ecstatic energetic fabric of the universe" was, my day to day life wasn't positively shifting because the light hadn't permeated my body's cells or my psychological conditioning. Inhabiting our humanness is embodied wholeness. Ultimately, if our spiritual epiphanies aren't impacting our lived experience, they are little more than momentary escapes.

If this film sincerely intends to instigate true healing, then I must encourage others to be transparent about their own traumas, before attempting to permanently transcend them. This order is crucial. The brightest light needs an anchor first. An anchor into what we wish to hide from the most, so that it too can receive illumination. I invite my audience to meditate on their anchor, before becoming poets themselves as I strive to in the conclusion of Letters From My

\section{Future Self.}

word count: 10913

48 “Jungcurrents.com," accessed May 5, 2019, http://jungcurrents.com/jung-shadow-darkness-conscious. 


\section{Bibliography/Mediagraphy}

Af Klint, Hilma, 1906-1915. Hilma af Klint: Paintings for the Future. New York Solomon R. Guggenhein Museum. Website. https://www.guggenheim.org/exhibition/hilma-af-klint. Accessed 15 December 2018.

“Beyond Addiction.” accessed Mar 24, 2019. http://beyondaddiction.ca/about.

"Bill Viola Five Angels for the Millennium 2001." Tate. accessed Dec 3, 2018. https://www. tate.org.uk/art/artworks/viola-five-angels-for-the-millennium-t11805.

"Bill Viola Interview: Cameras are Soul Keepers." video. 28:09. https://www.youtube.com/ watch? $\mathrm{v}=$ uenrts 2 YHdI\& $\mathrm{t}=2 \mathrm{~s}$.

“Bill Viola Nantes Triptych 1992.” Tate. accessed Dec 3, 2018. https://www.tate.org.uk/art/artworks/viola-nantes-triptych-t06854.

“Bill Viola.” Wikipedia. accessed Dec 3, 2018. https://en.wikipedia.org/wiki/Bill_Viola.

Cameron, Julia. The Artist's Way: A Spiritual Path to Higher Creativity. New York: Penguin Random House, 1992.

Chinmoy, Sri. Art's Life and the Soul's Light. New York: Agni Press, 1974.

“David Whyte." accessed Dec 3, 2018. http://www.davidwhyte.com/english-poetry/.

Farrokhzad, Forugh. Sin: Selected Poems of Forugh Farrokhzad. Arkansas: University Of Arkansas Press, 2010.

“Forough Farrokhad." Wikipedia. accessed Dec 3, 2018. https://en.wikipedia.org/wiki/For ough_Farrokhzad.

Foucault, Michel. "What is Enlightenment." In The Foucault Reader, 32-50. New York: Vintage Books, 1984.

"Future Self with Jac and Tara." Vimeo unlisted video, 22:49. Posted by "GOTEAMLIGHT," March 2018. https://vimeo.com/258968116/3ef23e025b.

Herman, Judith. Trauma and Recovery. New York: BasicBooks, 1992.

"Hilma af Klint: Paintings for the Future." The Guggenheim. accessed Dec 3, 2018. https:// www.guggenheim.org/exhibition/hilma-af-klint. 
Hoolboom, Mike. Practical Dreamers: Conversations with Movie Artists. Toronto: Coach House Books, 2008.

Hoolboom, Mike. The Beauty Is Relentless: The Short Movies of Emily Vey Duke and Cooper Battersby. Toronto: Museum of Contemporary Canadian Art and Pleasure Dome, 2012.

“Jungcurrents.com.” accessed May 5, 2019. http://jungcurrents.com/jung-shadow-darknessconscious.

Levine, Peter. "Good Reads." accessed May 7, 2019. https://www.goodreads.com/author/ quotes/142956.Peter_A_Levine.

"Lotus Yoga." accessed Mar 22, 2019. https://www.lotusyogacentre.com/addiction-workshopjan-2019/.

"Mary Oliver, The Journey." accessed Mar 22, 2019. http://www.phys.unm.edu/ tw/fas/yits/ archive/oliver_thejourney.html.

McDowell, Robert. Poetry As Spiritual Practice. New York: Simon \& Schuster, 2008. "Radical Humanism and the Coexistence of Film and Poetry in THE HOUSE IS BLACK." Jonathan Rosenbaum. accessed Dec 3, 2018. http://www.jonathanrosen baum.net/2001/04/tradical-humanism-and-the-coexistence-of-film-and-poetry-in-thehouse-is-black/.

“Meister Eckhart." accessed Mar 22, 2019. https://en.wikiquote.org/wiki/Meister_Eckhart.

Murdock, Maureen. The Heroine's Journey: Woman's Quest for Wholeness. Boulder, Colorado: Shambala Publications Inc., 1990.

Payzant, Geoffrey. Glenn Gould Music \& Mind. Toronto: Key Porter Books, 2005.

"Quantum Theory Predicts that the Future Could Be Influencing the Past (yes you read that correctly)." accessed Mar 24, 2018. http://www.collective-evolution.com/2017/09/19/ quantum-theory-predicts-that-the-future-could-be-influencing-the-past-yes-you-readthat-correctly/.

Ravenal, John B. Outer \& Inner Space. Pipilotti Rist, Shirin Neshat, Jane \& Louise Wilson, and the History of Video Art. VA: University of Washington Press, 2002.

"Resurrecting Jesus: Embodying the Spirit of a Revolutionary Mystic By Adyashanti." Huffpost. accessed Dec 3, 2018. https://www.huffingtonpost.com/2014/04/19/resurrecting-jesusrevolu_n_5170141.html. 
Rist, Pipilotti, 2009. Pour Your Body Out. Moma. Website. https://www.moma.org/calendar/ exhibitions/307. Accessed 15 December 2018.

Rist, Pipilotti, 2016. 4th Floor to Mildness. New Museum. Website. https://

www.newmuseum.org/calendar/view/1137/new-perspectives-tour-of-pipilotti-rist-pixelforest-4. Accessed 15 December 2018.

Ross, David, and Peter Sellars. Bill Viola. New York: Whitney Museum of American Art, 1998.

"Rumi," Goodreads, accessed Dec 3, 2018, https://www.goodreads.com/quotes/13186-i-havelived-on-the-lip-of-insanity-wanting-to.

"The Future is Fluid." The Rubin. accessed Dec 3, 2018. http://rubinmuseum.org/theme/the-fu ture.

“The Heroine's Journey,” accessed Apr 21, 2018. http://www.maureenmurdock.com/articles/ articles-the-heroines-journey/.

The House Is Black. Film. Directed by Forough Farrokhzad. Persia. 1963.

Trollback + Company, March 1 2018. Three Perspectives On Time. Rubin Museum. Website. http://rubinmuseum.org/mediacenter/three-perspectives-on-time. Accessed 15 December 2018.

“True Autonomy.” Adyashanti. accessed Dec 3, 2018. https://www.adyashanti.org/index.php? file=writings_inner\&writingid $=44$.

Varzi, Roxanne. "Pictura Poesis: The interplay of poetry, image and ethnography in Forough Far rokhzad's The House is Black." Off Screen 18, Iss. 9 (2014). https://offscreen.com/view/ house-is-black.

Wilson, Shawn. "What is Indigenous Research Methodology." Canadian Journal of Native Education 25, no. 2 (2001): 178.

Wright, Kenneth. Mirroing and Attunment: Self-Realization in Psychoanalysis and Art. New York: Routledge, 2009.

“Zen Irodalom Zen Literature.” accessed Dec 14, 2018. https://terebess.hu/zen/qingyuan.html.

Word Count: 10, 914 